\title{
46. DIFFUSING FACTORS
}

\section{THE EFFECT OF SALTS ON THE ACTION OF TESTICULAR EXTRACTS ON THE VISCOSITY OF VITREOUS HUMOUR PREPARATIONS}

\author{
BY J. MADINAVEITIA ${ }^{1}$ AND T. H. H. QUIBELL \\ From the Chemistry Department, University of Manchester
}

(Received 10 March 1941)

THE reduction of the viscosity of certain mucins by testicular extracts and by mucinases from other sources of diffusing factors has been associated by Chain \& Duthie [1939] with the characteristic spreading properties of these factors. Comparison of the relative diffusing and mucolytic activities of diffusing factor preparations [Madinaveitia et al: 1940] requires a relatively accurate quantitative estimation of the two effects. Methods are now available which permit such a comparison to be carried out; the diffusing activity can be determined with enough accuracy by the technique of Bacharach et al. [1940] and the available viscosimetric method [Madinaveitia \& Quibell, 1940] accurately measures mucolytic activity. The results obtained by these methods do not quite agree with the view that the effect of diffusing factors is solely due to the mucolytic activity of the assayed preparations.

The viscosimetric method for the estimation of mucinases is based on the fact that the rate of decrease of the viscosity of vitreous humour preparation is proportional to the concentration of enzyme present in the reacting mixture, provided that the reaction is carried out under certain conditions. The mucolytic activities of a number of diffusing factor preparations have now been compared by this method. The results obtained are in good agreement when comparison is made at different concentrations of enzyme $(c)$ after the original viscosity of the substrate $\left(\eta s p_{0}\right)$ has been reduced to a given value $\left(\% \eta s p_{0}\right)$. The product of the concentration of enzyme and the time $(t)$ required to reach the chosen viscosity level $(c \times t)$ is practically constant for each preparation whatever is the decrease in the viscosity, provided that it is the same for all the samples compared (Table i).

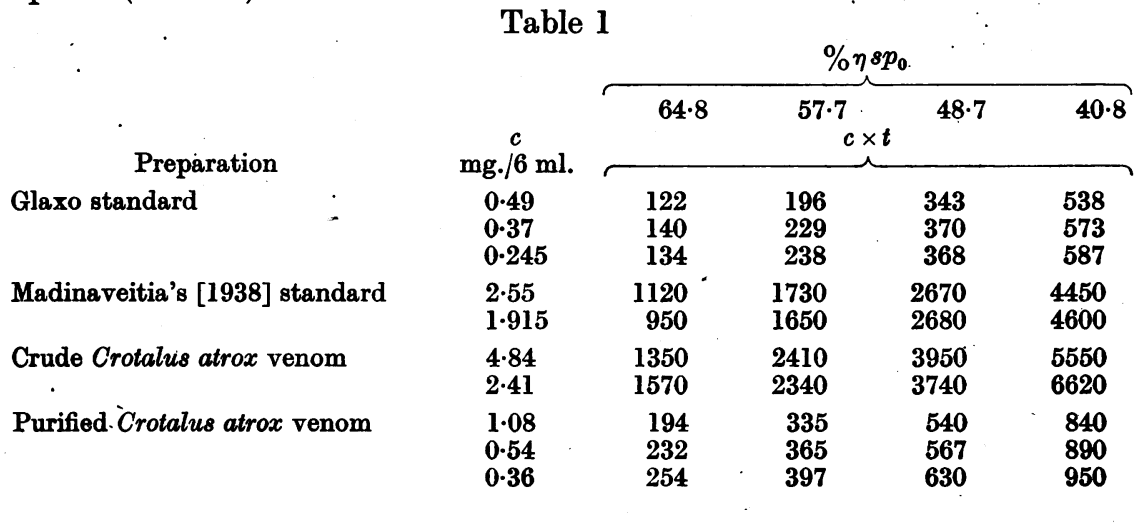

1 Beit Memorial Research Fellow. 
Using one preparation as a standard of reference, the relative mucolytic activity of each of the others is the same irrespective of the viscosity level at which comparison is carried out (Table 2).

\begin{tabular}{|c|c|c|c|c|}
\hline \multirow[b]{2}{*}{ Preparation } & \multicolumn{4}{|c|}{$\% \eta s p_{0}$} \\
\hline & \multicolumn{4}{|c|}{$\begin{array}{l}63 \cdot 5 \\
\text { Ratio to Glaxo Standard }\end{array}$} \\
\hline $\begin{array}{l}\text { From testicle: } \\
\text { Glaxo standard } \\
\text { Madinaveitia standard } \\
M / 10 \text { acetic acid extract } \\
\left(\mathrm{NH}_{4}\right)_{2} \mathrm{SO}_{4} \text {-purified }\end{array}$ & $\begin{array}{l}100 \\
23 \cdot 5 \\
84 \\
150\end{array}$ & $\begin{array}{l}100 \\
24 \cdot 7 \\
85 \\
152\end{array}$ & $\begin{array}{c}100 \\
23 \cdot 2 \\
79 \\
147\end{array}$ & $\begin{array}{c}100 \\
24 \cdot 2 \\
67 ? \\
147\end{array}$ \\
\hline From Crotalus atrox: & & & & \\
\hline $\begin{array}{l}\text { Crude venom } \\
\left(\mathrm{NH}_{4}\right)_{2} \mathrm{SO}_{4} \text {-purified venom }\end{array}$ & $\begin{array}{l}19 \cdot 9 \\
51 \cdot 5\end{array}$ & $\begin{array}{l}17 \\
57 \cdot 5\end{array}$ & $\begin{array}{l}15 \cdot 7 \\
67\end{array}$ & $\begin{array}{l}15 \cdot 9 \\
69\end{array}$ \\
\hline
\end{tabular}

All comparisons were carried out under the conditions originally suggested [Madinaveitia \& Quibell, 1940], i.e. in $0.66 \mathrm{M} \mathrm{NaCl}$ and in the presence of $0 \cdot 18 \mathrm{M}$ citrate buffer $p H 4 \cdot 7$. However, on testing by this method a mucinase preparation from Clostridium welchii prepared by Dr D. McClean of the Lister Institute we found that contrary to his indications it was practically inactive. This apparent discrepancy was due to the fact that Dr McClean's estimation of the mucolytic activity of this preparation had been carried out in the absence of $\mathrm{NaCl}$. In view of this an investigation has now been carried out on the effect of salts on the reaction in which the viscosity of vitreous humour preparations is destroyed by the action of testicular extracts. A summary of the results has already been published [Madinaveitia \& McClean, 1940]. The substrate used was prepared from an acetone powder of bovine vitreous humour (1 g.) by extraction with $M / 50 \mathrm{NaOH}(50 \mathrm{ml}$.) and precipitation of the centrifuged and acidified (10 ml. $M$ acetic acid) extract with 6 vol. acetone. After washing the precipitate with ether and drying in vacuo a white powder was obtained which was almost completely soluble in water but which still contained some salts. The source of enzyme was a preparation obtained by $\left(\mathrm{NH}_{4}\right)_{2} \mathrm{SO}_{4}$-fractionation from an acetic acid (2 1. $M / 10)$ extract of dry testicle powder $(100 \mathrm{~g}$.). The material precipitated between 30 and $70 \%$ of saturation was redissolved, dialysed, subsequently electrodialysed until the conductivity was practically constant and finally dried whilst frozen. It was salt-free. The.techniques used for estimating the viscosity and for determining the helf-life time of the viscous substrate were those already described [Madinaveitia \& Quibell, 1940].

As previously reported addition of salts has the effect of decreasing the specific viscosity $\left(\eta s p_{0}\right)$ of the substrate (Tables 3 and 5). However, the relationship between specific viscosity and the concentration of the substrate is the same at any given $\mathrm{NaCl}$ concentration as indicated by the fact that the ratio of the viscosity of the substrate $\left(\eta s p_{0}\right)$ to that of the substrate diluted with 1 vol. of the corresponding $\mathrm{NaCl}$ solution $\left(\eta s p_{\frac{1}{2}}\right)$ is constant (Table 3). The only ratio owhich differs significantly from the others is that in which there is no $\mathrm{NaCl}$ present but this can be easily accounted for by the fact that the vitreous humour preparation used was not absolutely free of electrolytes. Reduction of the concentration of electrolyte on dilution with distilled water would render the more diluted substrate somewhat more viscous than expected. Electrodialysis throws the viscous materials out of solution. 
When a series of samples of electrodialysed enzyme $\left(0.5^{\prime} \mathrm{mg}\right.$. in $1 \mathrm{ml}$. water) are allowed to react with a substrate solution $(5 \mathrm{ml} .2 \%$ ) in $\mathrm{NaCl}$ of increasing concentration the half-life time $(t)$ of the viscous material decreases as the concentration of $\mathrm{NaCl}$ in the reacting mixture becomes larger and after reaching a minimum it increases again (Table 3). Therefore there is an optimum salt concentration for the activity $\left(t^{-1}\right)$ of the enzyme.

Table 3

\begin{tabular}{|c|c|c|c|c|c|}
\hline$\underset{\boldsymbol{M}}{\mathrm{NaCl}}$ & $\eta s p_{0}$ & $\eta s p_{\sharp}$ & $\frac{\eta \delta p_{0}}{\eta s p_{i}}$ & $\underset{\text { min. }}{t}$ & $t^{-1}$ \\
\hline 0.00000 & 1.44 & 0.752 & 1.92 & 60 & 0.012 \\
\hline 0.00083 & 1.28 & 0.596 & $2 \cdot 14$ & 30 & 0.033 \\
\hline 0.00167 & $1 \cdot 12$ & 0.513 & $2 \cdot 18$ & $15 \cdot 5$ & 0.064 \\
\hline 0.00334 & 0.94 & 0.443 & $2 \cdot 13$ & $12 \cdot 5$ & 0.080 \\
\hline 0.00500 & 0.850 & - & - & 12.5 & 0.080 \\
\hline 0.00667 & 0.775 & 二 & 二 & 9.0 & $0 \cdot 112$ \\
\hline 0.00833 & 0.725 & 0.339 & $2 \cdot 14$ & $6 \cdot 0$ & 0.167 \\
\hline 0.01677 & 0.593 & 0.279 & $2 \cdot 13$ & $4 \cdot 2$ & 0.238 \\
\hline 0.0334 & 0.491 & 0.234 & $2 \cdot 10$ & $3 \cdot \overline{3}$ & 0.303 \\
\hline 0.0500 & 0.441 & - & - & $2 \cdot 3$ & 0.425 \\
\hline 0.0667 & 0.417 & - & - & 0.7 & 1.43 \\
\hline 0.0833 & 0.400 & - & - & 0.7 & 1.43 \\
\hline 0.167 & 0.339 & - & - & 0.7 & 1.43 \\
\hline 0.334 & 0.308 & - & - & $3 \cdot 0$ & 0.333 \\
\hline 0.500 & 0.289 & - & - & $3 \cdot 2$ & 0.312 \\
\hline 0.667 & 0.283 & - & - & $4 \cdot 7$ & 0.213 \\
\hline 0.833 & 0.270 & - & - & 14.5 & 0.069 \\
\hline $\begin{array}{l}1.670 \\
0\end{array}$ & 0.259 & - & - & 30 & 0.033 \\
\hline
\end{tabular}

The same effect was observed when a similar experiment was carried out in the presence of $0.2 M$ citrate buffer $p H 4.7$ and with concentrations of substrate and of enzyme different from those in the previous experiment. The same picture is obtained at whatever fraction of the original viscosity the comparison is carried out (Table 4). In addition to $\mathrm{NaCl}$ certain other salts in dilute solution

Table 4

\begin{tabular}{cccccccc} 
NaCl & \multicolumn{7}{c}{$\% \eta s p_{0}$} \\
$M$ & 65 & 60 & 55 & 50 & 45 & 40 \\
& \multicolumn{7}{c}{ Sec. required to reach $\% \eta s p_{0}$} \\
0.00 & 300 & 380 & 900 & 1580 & 2400 & 3500 \\
0.01 & 190 & 240 & 310 & 440 & 700 & 1050 \\
0.02 & 160 & 240 & 350 & 530 & 880 & 1450 \\
0.05 & 100 & 190 & 320 & 500 & 750 & 1050 \\
0.10 & 130 & 210 & 370 & 550 & 820 & 1250 \\
0.16 & 110 & 240 & 330 & 480 & 700 & 1050 \\
0.21 & 130 & 240 & 370 & 550 & 820 & 1250 \\
0.53 & 150 & 290 & 500 & 850 & 1320 & 2100 \\
1.56 & 170 & 1050 & 1900 & - & - & - \\
2.08 & 1300 & 2900 & 5000 & - & - & -
\end{tabular}

also enhance the action of the enzyme and all the salts examined inhibit at relatively high concentrations. In Table 5 the effect of increasing amounts of $\mathrm{NaCl}$ is compared with that of other salts. The reaction was carried out in the presence of $0 \cdot 2 M \mathrm{Na}$ citrate buffer $p H 4 \cdot 7$.

The method suggested [Madinaveitia \& Quibell, 1940] for the comparison of the activities of mucinase preparations depends on the half-life time of the substrate being inversely proportional to the concentration of enzyme. This relationship does not hold good when working in an unbuffered solution at low 


\begin{tabular}{|c|c|c|c|c|c|c|}
\hline \multicolumn{7}{|c|}{ Table 5} \\
\hline & $t$ & $\eta s p_{0}$ & $t$ & $\eta s p_{0}$ & $t$ & $\eta s p_{0}$ \\
\hline $\begin{array}{l}\text { Without salt } \\
\text { Molarity of salt }\end{array}$ & 15 & $3^{0.515}$ & 15 & $3^{0.515}$ & 15 & $0.83^{0.515}$ \\
\hline $\mathrm{NaCl}$ & 7.5 & 0.430 & 7 & 0.392 & 29.5 & 0.330 \\
\hline $\mathrm{KCl}$ & 7.5 & 0.435 & 7 & 0.402 & $29 \cdot 5$ & $0 \cdot 326$ \\
\hline $\mathrm{NH}_{4} \mathrm{Cl}$ & $5 \cdot 5$ & 0.472 & $5 \cdot 5$ & 0.458 & 45 & $0 \cdot 310$ \\
\hline $\mathrm{NaI}$ & $11 \cdot 5$ & 0.404 & $13 \cdot 5$ & 0.382 & 100 & 0.325 \\
\hline $\mathrm{NaBr}$ & $9 \cdot 5$ & 0.418 & $9 \cdot 5$ & $0 \cdot 398$ & 95 & $0 \cdot 320$ \\
\hline $\mathrm{Na}_{2} \mathrm{SO}_{4}$ & 15 & 0.422 & 40 & $0 \cdot 407$ & 200 & 0.450 \\
\hline
\end{tabular}

$\mathrm{NaCl}$ concentrations. Under these conditions, when the concentration of enzyme is increased, the half-life time of the substrate decreases much more rapidly than expected (Fig. 1). This effect is most marked in the absence of $\mathrm{NaCl}$ and it becomes less noticeable as the concentration of salt increases. After a certain level of salt concentration has been reached the half-life time of the substrate becomes inversely proportional to the concentration of enzyme and thereafter this relationship is maintained although the reaction velocity decreases.

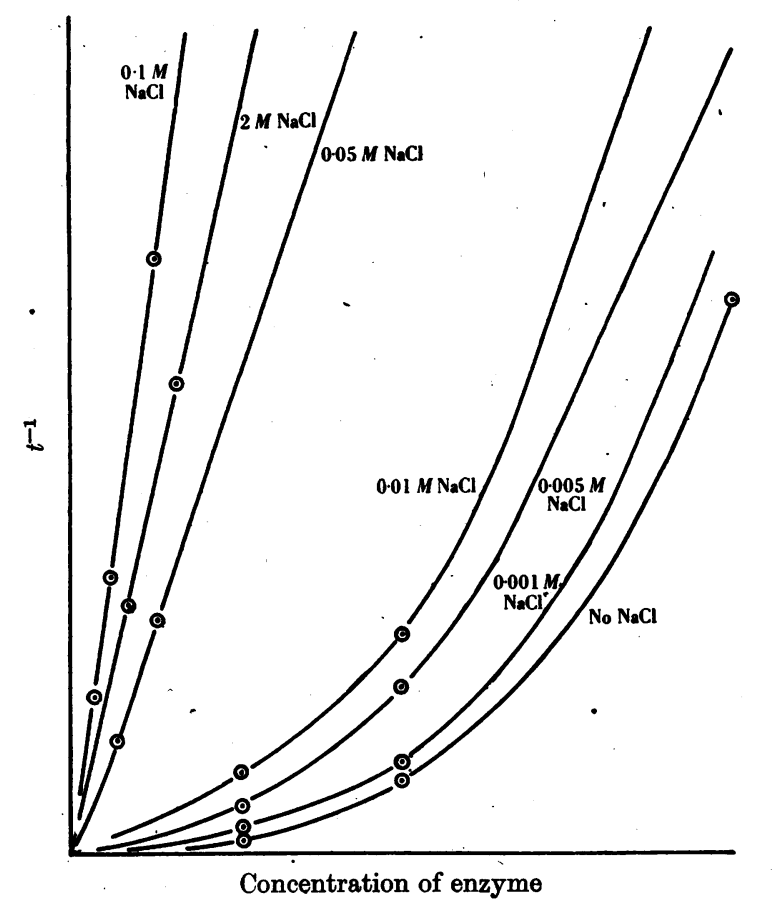

Fig. 1. Effect of the concentration of $\mathrm{NaCl}$ on the dose-response curve of testicular mucinase.

Testicular mucinase is not the only enzyme whose action is enhanced by the presence of salts. The effect of neutral salts on the action of different amylases is well known and has been studied in some detail [cf. Myrbäck, 1926; Sherman et al. 1928]. It has been found that some ions increase the activity of amylases, changing the $p \mathrm{H}$ optimum. An alteration of the kinetics of the reaction between amylase and starch due to the presence of $\mathrm{NaCl}$, such as observed with testicular mucinase, has never been recorded as far as we are aware. 


\section{SUMMARY}

The time required to reduce the viscosity of vitreous humour preparations to half its original value is inversely proportional to the concentration of testicular mucinase present in the reacting mixture, provided that the reaction is carried out in the presence of $\mathrm{NaCl}$. At low concentrations of salt this time decreases very rapidly as the concentration of enzyme increases.

The authors' thanks are due to Prof. A. R. Todd for his continued interest and advice. They are also grateful to Dr D. McClean of the Lister Institute for supplies of bacterial filtrates and much useful discussion. Grants from Imperial Chemical Industries are gratefully acknowledged.

\section{REFERENCES}

Bacharach, Chance \& Middleton. (1940). Biochem. J. 34, 1464.

Chain \& Duthie (1939). Nature, Lond. 144, 977.

Madinaveitia (1938). Biochem. J. 32, 1470.

__ \& McClean (1940). J. Soc. Chem. Ind., Lond. 59, 418.

\& Quibell (1940). Biochem. J. 34, 625.

Todd, Bacharach \& Chance (1940). Nature, Lond. 146, 197.

Myrbäck (1926). Hoppe-Seyl. Z. 159, 1.

Sherman, Caldwell \& Adams (1928). J. Amer. chem. Soc. 502535. 